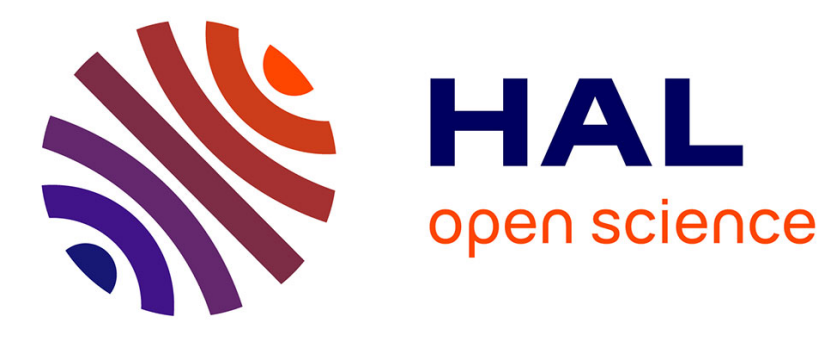

\title{
Highly Selective Fluoride Recognition by a Small Tris-Urea Covalent Cage
}

\author{
Magalie Delecluse, Cédric Colomban, Bastien Chatelet, Sabine
}

Chevallier-Michaud, Delphine Moraleda, Jean-Pierre Dutasta, Alexandre

Martinez

\section{To cite this version:}

Magalie Delecluse, Cédric Colomban, Bastien Chatelet, Sabine Chevallier-Michaud, Delphine Moraleda, et al.. Highly Selective Fluoride Recognition by a Small Tris-Urea Covalent Cage. Journal of Organic Chemistry, 2020, 85 (7), pp.4706-4711. 10.1021/acs.joc.9b03429 . hal-02863548

\section{HAL Id: hal-02863548 \\ https://hal.science/hal-02863548}

Submitted on 24 Mar 2021

HAL is a multi-disciplinary open access archive for the deposit and dissemination of scientific research documents, whether they are published or not. The documents may come from teaching and research institutions in France or abroad, or from public or private research centers.
L'archive ouverte pluridisciplinaire HAL, est destinée au dépôt et à la diffusion de documents scientifiques de niveau recherche, publiés ou non, émanant des établissements d'enseignement et de recherche français ou étrangers, des laboratoires publics ou privés. 


\title{
Highly Selective Fluoride Recognition by a Small Tris-Urea Covalent Cage
}

\author{
Magalie Delecluse, Cédric Colomban,* Bastien Chatelet, Sabine Chevallier-Michaud, \\ Delphine Moraleda, Jean-Pierre Dutasta, and Alexandre Martinez*
}

ABSTRACT: A highly selective recognition of fluoride was achieved through the design of a small hemicryptophane cage (3) presenting a southern tris-urea hosting moiety. The resulting host-guest complex has been characterized by electrospray ionization-highresolution mass spectrometry, ${ }^{1} \mathrm{H}$ and ${ }^{19} \mathrm{~F} \mathrm{NMR}$, and X-ray diffraction techniques. In particular, X-ray diffraction analysis of $\left[3 \cdot \mathrm{F}^{-}\right]$reveals that the encapsulation of one fluoride, within 3, occurs through $\mathrm{NH} \cdots \mathrm{F}^{-} \mathrm{H}$-bonding with the six $\mathrm{NH}$ residues of the tris-urea ligand. An association constant of $1200 \mathrm{M}^{-1}$ was extracted from ${ }^{1} \mathrm{H}$ NMR titration experiments, indicating that efficient fluoride binding also occurs in solution. Finally, in sharp contrast with previously reported urea-based hemicryptophane hosts, the small preorganized cavity found in $\mathbf{3}$ allows for an exclusive selectivity for fluoride over other competing halides.

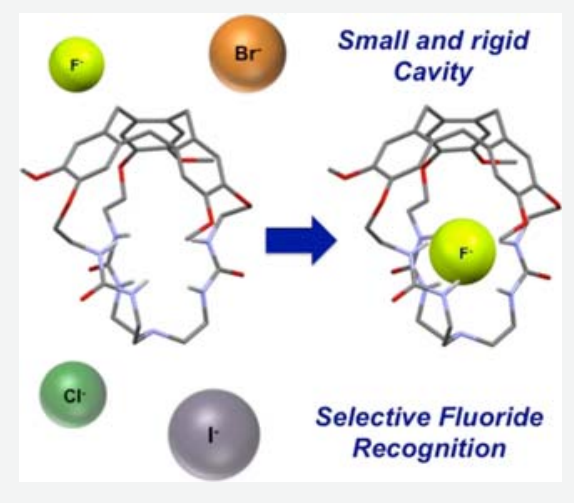

\section{INTRODUCTION}

The discovery of new artificial receptors that exclusively recognize the fluoride anion is of particular interest due to the variety of potential applications ranging from positron emission tomography (biomedicine), monitoring, and removal from drinking water (environmental science) to fluoride-based batteries (energy). ${ }^{1}$ Although numerous anion receptors and sensors have been developed over the past decade, ${ }^{2}$ very few examples of receptors displaying exclusive selectivity for fluoride could be found in the literature. ${ }^{3}$ The exclusive binding of the fluoride anion is indeed a particularly challenging task due to its small ionic radius, high charge density, and Lewis basicity. Among the various strategies reported for the binding of $\mathrm{F}^{-}$, the two main approaches rely on artificial receptors that either induce hydrogen-bonding interactions ${ }^{4}$ or present a Lewis acid center. It is in this last category that uranyl, ${ }^{5}$ boron, ${ }^{6}$ antimony, ${ }^{7}$ or transition metalbased hosts ${ }^{8}$ have been developed aiming at establishing complexes with fluoride. Among receptors capable of selectively chelating fluoride via hydrogen-bonding interactions, the use of preorganized cyclic urea-based ligand has recently appeared as a particularly promising strategy.

Lately in our laboratory, we incorporated a tris-urea motif into a hemicryptophane structure to form the cage molecule 2. ${ }^{10}$ Cage 2 displays a northern cyclotriveratrylene (CTV) linked to the tris-urea by aryl linkers (Figure 1). Compared to its parent cage $\mathbf{1}$, built from a tris-amide southern unit, ${ }^{11} \mathbf{2}$ displayed an improved binding constant for fluoride (3900 $\mathrm{M}^{-1}$ vs $120 \mathrm{M}^{-1}$ in $\mathrm{CDCl}_{3}$ ), highlighting the crucial role of the southern tris-urea recognition center. However, hemicrypto- phane 2 displayed poor fluoride selectivity over other competing small halides. Typically, modest values of 3.7 and 0.95 were observed for the binding constant ratio $K_{\mathrm{F}^{-}} / \mathrm{K}_{\mathrm{Br}}{ }^{-}$and $K_{\mathrm{F}}^{-} / K_{\mathrm{Cl}^{-}}$, respectively. Clearly, the large cavity found in $\mathbf{2}$ is not compatible with an exclusive binding of the small fluoride anion. On this basis, we reasoned that the building of a trisurea-based hemicryptophane displaying shorter linkers might result in a more selective receptor. Indeed, Sessler, Kim, and co-workers have recently demonstrated that a remarkable complete selectivity for fluoride (over other small anions) could be achieved by lowering the size and improving the structural rigidity of a triiminopyrrolic molecular cage. ${ }^{12}$

Herein, we therefore present the design and preparation of the novel hemicryptophane 3 , in which the northern CTV unit is now connected to the tris-urea ligand by short ethylene $-\mathrm{C}_{2} \mathrm{H}_{4}-$ bridges. We observed, through a combination of electrospray ionization-high-resolution mass spectrometry (ESI-HRMS), ${ }^{1} \mathrm{H}$ NMR, ${ }^{19} \mathrm{~F}$ NMR, and X-ray diffraction (XRD) analysis, that the $\mathrm{F}^{-}$atom is efficiently entrapped in the cage 3, through $\mathrm{NH} \cdots \mathrm{F}^{-}$hydrogen-bonding interactions with the six NH residues. Finally, in sharp contrast with the previously reported host 2 , we demonstrate that the 


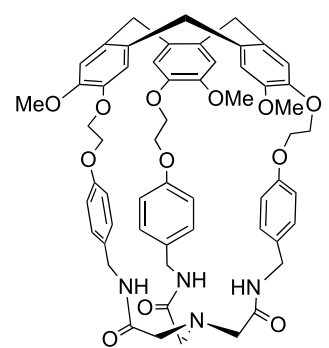

1

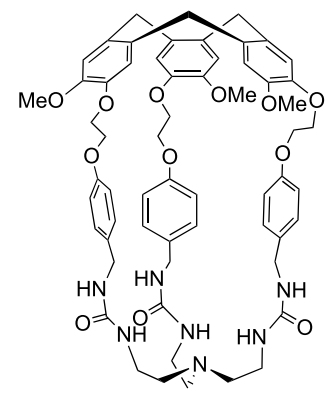

2

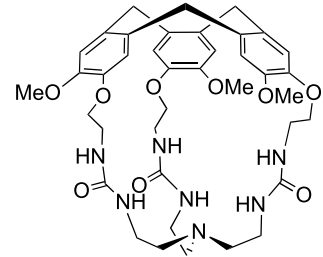

3

Figure 1. Structure of hemicryptophanes 1, 2, and 3.

\section{Scheme 1. Synthesis of Hemicryptophane 3}
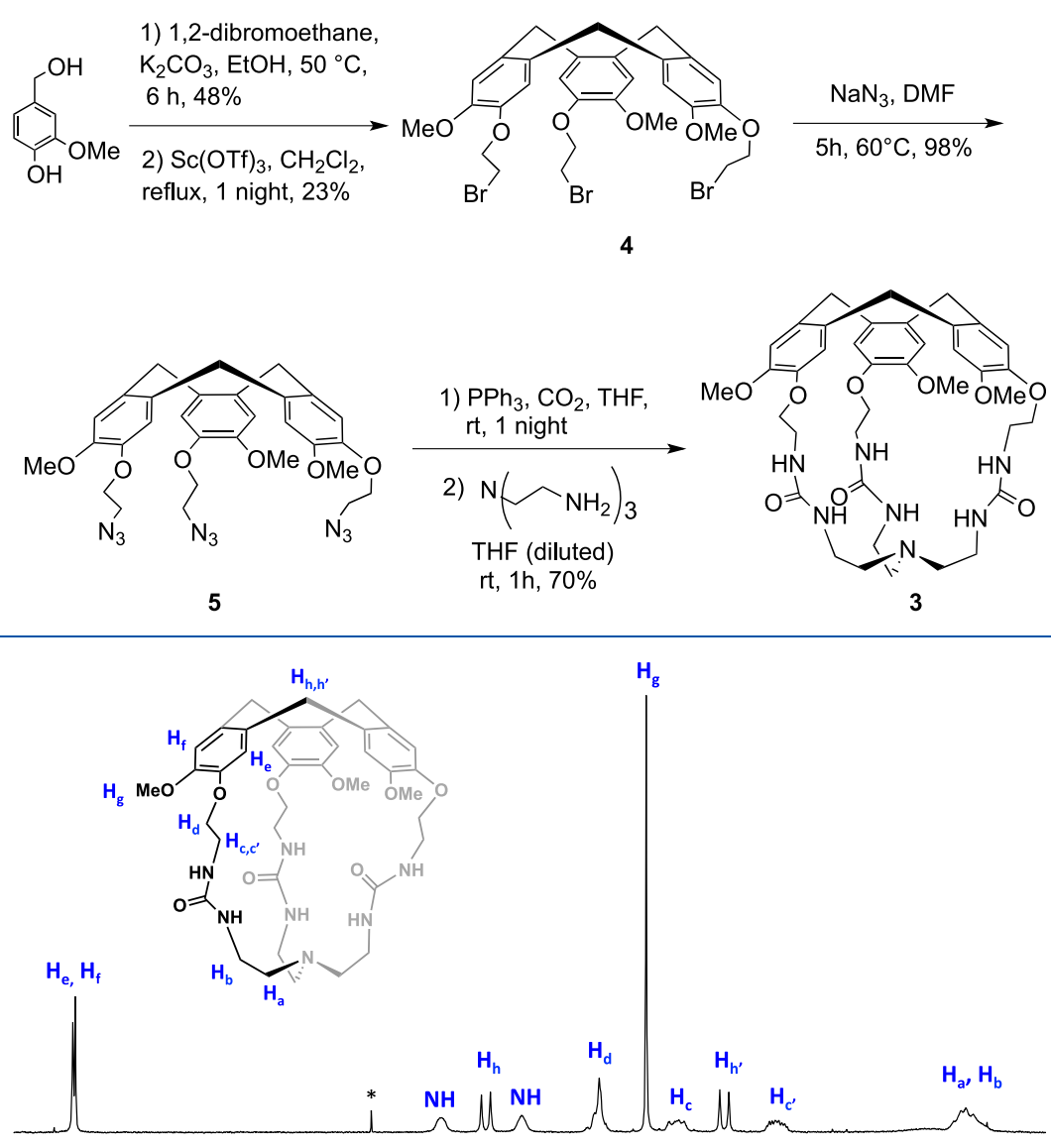

$\begin{array}{llllllllllllllllllllllllllllll}7.0 & 6.8 & 6.6 & 6.4 & 6.2 & 6.0 & 5.8 & 5.6 & 5.4 & 5.2 & 5.0 & 4.8 & 4.6 & 4.4 & 4.2 & 4.0 & 3.8 & 3.6 & 3.4 & 3.2 & 3.0 & 2.8 & 2.6 & 2.4 & 2.2 & 2.0\end{array}$

Figure 2. ${ }^{1} \mathrm{H}$ NMR spectrum $\left(400 \mathrm{MHz}, \mathrm{CDCl}_{3}\right)$ of $3\left(*=\mathrm{CH}_{2} \mathrm{Cl}_{2}\right)$.

structurally contracted cavity of 3 allows for a remarkable exclusive selectivity for fluoride compared to other halides.

\section{RESULTS AND DISCUSSION}

Hemicryptophane 3 was prepared following a 5 step synthetic route (Scheme 1). A reported procedure affords the expected CTV derivative 4 in two steps: the reaction between 1,2dibromoethane and vanillyl alcohol was followed by a FriedelCraft reaction catalyzed by scandium triflate, giving compound 4 ( $11 \%$ yields over the two steps). ${ }^{13}$ CTV 4 was then treated by sodium azide, using dimethylformamide (DMF) as a solvent to afford the CTV derivative $\mathbf{5}$ in $98 \%$ yield. The subsequent bubbling of $\mathrm{CO}_{2}$ converts the azide functions of 5 into isocyanates that further react, under high dilution conditions, with the tris-(2-aminoethyl)amine (tren) ligand, providing the targeted cage 3 in $70 \%$ yield.

In line with previously reported hemicryptophane derivatives, ${ }^{1} \mathrm{H}$ NMR analysis of $\mathbf{3}$ in deuterated chloroform indicates that the cage displays an effective $C_{3}$ symmetry on average (Figure 2). ${ }^{14} \mathrm{H}$ NMR signals of the protons belonging to the CTV moiety are resonating as two singlets for the aromatic protons $\left(\mathrm{H}_{\mathrm{e}}, \mathrm{H}_{\mathrm{f}}\right)$ at $\delta=6.81$ and $6.80 \mathrm{ppm}$, two doublets for diastereotopic methylene $\left(\mathrm{CH}_{2}-\mathrm{Ar}\right)$ protons $\left(\mathrm{H}_{\mathrm{h}, \mathrm{h}^{\prime}}\right)$ at $\delta=4.71$ and $3.50 \mathrm{ppm}\left(J_{\mathrm{HH}}=13.6 \mathrm{~Hz}\right)$, and one singlet for the $\mathrm{OMe}$ 
group $\left(\mathrm{H}_{\mathrm{g}}\right)$ at $\delta=3.90 \mathrm{ppm}$. The diastereotopic ethylene protons of the linkers $\left(\mathrm{O}-\mathbf{C H}_{2}-\mathbf{C H}_{2}-\mathrm{O}, \mathrm{H}_{c, c^{\prime}}\right.$, and $\left.\mathrm{H}_{d}\right)$ exhibit the expected multiplets between 4.14 and $3.24 \mathrm{ppm}$. Finally, $\mathrm{NH}$ protons of the urea moiety and tren protons $(\mathrm{N}-$ $\mathbf{C H}_{2}-\mathbf{C H}_{2}-\mathrm{N}, \mathrm{H}_{2}, \mathrm{H}_{\mathrm{b}}$ ) appear as broad signals at $\delta=4.95$ and $4.54 \mathrm{ppm}$ and between 2.36 and $2.15 \mathrm{ppm}$, respectively. The assignment of these chemical shifts was achieved by means of 2D NMR analysis (Figure S6).

The recognition properties of cage 3 were then investigated through the ${ }^{1} \mathrm{H}$ NMR titration experiment between the host and fluoride (Figure 3). Tetra- $n$-butylammonim $\left(\mathrm{TBA}^{+}\right)$was

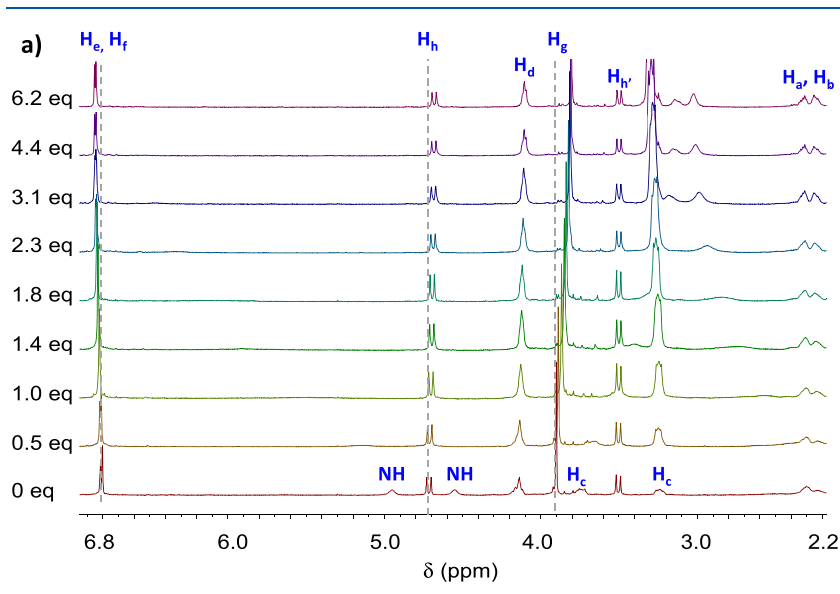

b)

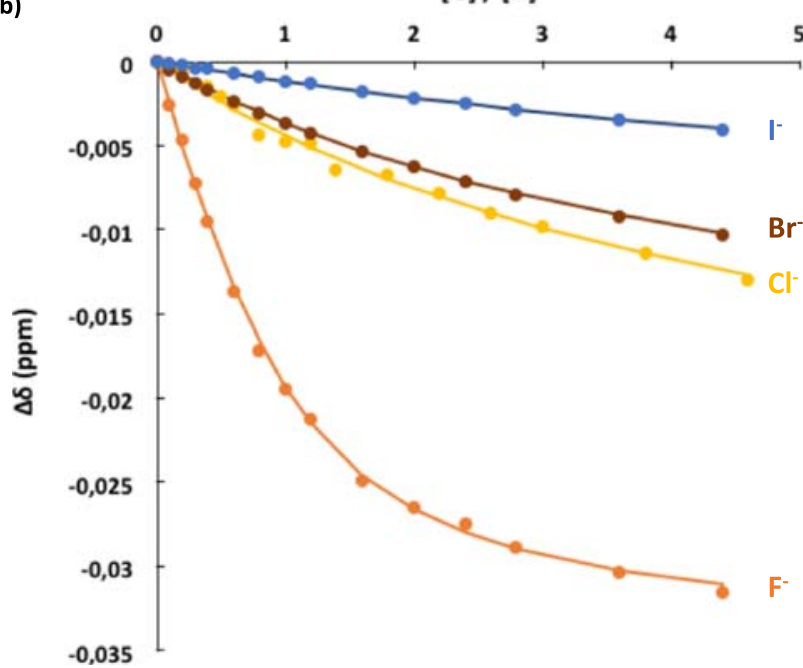

Figure 3. (a) Titration of cage $3(2.5 \mathrm{mM})$ with $\mathrm{F}^{-}$(TBAF salt, 25 $\mathrm{mM}$ ) in $\mathrm{CDCl}_{3}$. (b) Titration curves of the titration between cage 3 and TBA-halide salts in $\mathrm{CDCl}_{3}$ (see Figures $\mathrm{S} 7$ and $\mathrm{S} 8$ for other anions). Plots of the chemical induced shifts $(\Delta \delta)$ of the receptor's protons resonating at $4.71 \mathrm{ppm}$ as a function of the [guest]/[host] ratio are presented $\left(\mathrm{I}^{-}\right.$: blue; $\mathrm{Br}^{-}$: brown, $\mathrm{Cl}^{-}$: yellow; and $\mathrm{F}^{-}$: orange curves).

chosen as the counterion because its size prevents its inclusion into the hemicryptophane's cavity. ${ }^{10}$ In the presence of substoechiometric amounts of the tetrabutylammoniumfluoride (TBAF) guest ( 0.5 equiv, Figure 3 ), the ${ }^{1} \mathrm{H}$ NMR analysis of 3 reveals a single set of signals for both the halidefree host 3 and its fluoride complex, attesting for a fast hostguest exchange on the NMR time scale. Although fast hostguest exchange of fluorine was also reported in the case of hemicryptophane $\mathbf{2}$, such behavior contrasts with the majority of small molecular cages for anion recognition, that often exhibit rather slow kinetic of binding on the NMR timescale. ${ }^{2,3}$ Interestingly, the signal related to the $\mathrm{NH}$ protons of the southern urea appeared broader and downfield shifted upon addition of fluoride guest, highlighting $\mathrm{NH} \cdots \mathrm{F}^{-}$hydrogenbonding interactions (Figure 3a). Finally, in contrast to the $\mathrm{NH}$ residues of the ureas, protons $\mathrm{H}_{\mathrm{e}}, \mathrm{H}_{\mathrm{f}}, \mathrm{H}_{\mathrm{g}}$, and $\mathrm{H}_{\mathrm{h}, \mathrm{h}}$, belonging to the CTV unit, displayed well-defined signals during the whole titration experiment. The shift (upon halide complexation) of the signal corresponding to the proton $\mathrm{H}_{h}$ was therefore plotted as a function of the host-guest ratio. The bind fit program was used to model experimental titration curves and an optimal fit was found for a 1:1 host/guest stoichiometry. ${ }^{15}$

On this basis, an association of $K_{\mathrm{a}}=1200 \mathrm{M}^{-1}$ was calculated for the interaction of 3 with $\mathrm{F}^{-}$. This association constant is in the same order of magnitude than the one reported for the parent cage $\mathbf{2}$ and is one order of magnitude higher than the one observed for 1, confirming the crucial role of the tris-urea binding motif. The encapsulation of $\mathrm{F}^{-}$in the cavity of 3 was further evidenced by ${ }^{19} \mathrm{~F}$ NMR spectroscopy. Indeed, the ${ }^{19} \mathrm{~F}$ NMR spectrum of TBAF in the presence of 1.2 equiv of 3 reveals only one fluorine resonance at $-107.1 \mathrm{ppm}$, that is clearly downfielded compared to the control sample of TBAF in $\mathrm{CDCl}_{3}$ which resonates at $-129.3 \mathrm{ppm}$ (Figure 4). It

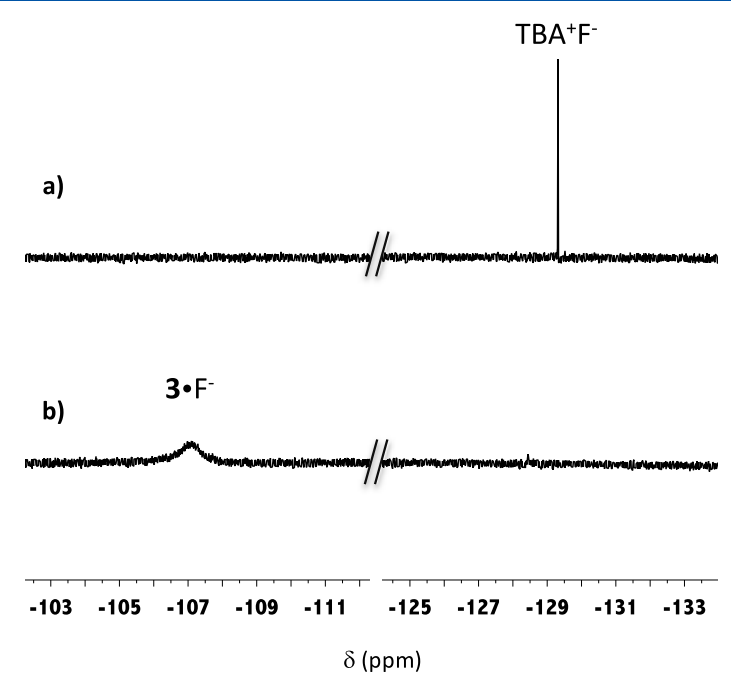

Figure 4. Partial ${ }^{19} \mathrm{~F}$ NMR spectra (fluorobenzene $\mathrm{C}_{6} \mathrm{H}_{5} \mathrm{~F}$ as external internal reference) of (a) TBAF alone in $\mathrm{CDCl}_{3}$ and (b) TBAF in $\mathrm{CDCl}_{3}(9.8 \mathrm{mM})$ in the presence of 1.2 equiv of cage 3 .

should be further noted that in contrast to triiminopyrrolic molecular cages, ${ }^{12}$ where pyrrolic $\mathrm{NH}$ protons are subject to deprotonation by $\mathrm{F}^{-}$, the urea $\mathrm{NH}$ protons in 3 remain stable upon additions of TBAF. Indeed, the ${ }^{1} \mathrm{H}$ and ${ }^{19} \mathrm{~F}$ NMRmonitored complexation of fluoride at 3 (Figures S7 and S8) did not reveal any formation of additional species such as protonated forms of $\mathrm{F}^{-}$(bifluoride anion $\mathrm{HF}_{2}^{-}$e.g.). ${ }^{16}$ Finally, ESI-HRMS analysis clearly supports the formation of $\left[3 \cdot \mathrm{F}^{-}\right]$in a 1:1 stoichiometry (Figure S9).

In order to clarify the $\mathrm{NH} \cdots \mathrm{F}^{-} \mathrm{H}$-bonding interactions postulated in $\left[3 \cdot \mathrm{F}^{-}\right]$, X-ray quality single crystals of $\left[3 \cdot \mathrm{F}^{-}\right]$ were grown by diffusion of $\mathrm{Et}_{2} \mathrm{O}$ to 3 and 1.6 equiv of TBAF dissolved in a $\mathrm{CHCl}_{3} / \mathrm{CH}_{3} \mathrm{CN}$ mixture (Figure S10). ${ }^{17} \mathrm{XRD}$ analysis unambiguously supports the binding of one $\mathrm{F}^{-}$anion within the cavity of 3 though six hydrogen bond with the $\mathrm{NH}$ 
residues of the tris-urea unit (average $\mathrm{NH} \cdots \mathrm{F}^{-}$distance of 2.1 $\AA$, Figure 5). Importantly, to the best of our knowledge, the later represents the first XRD structure of an anionic guest entrapped inside the cavity of a hemicryptophane molecular cage. ${ }^{1}$

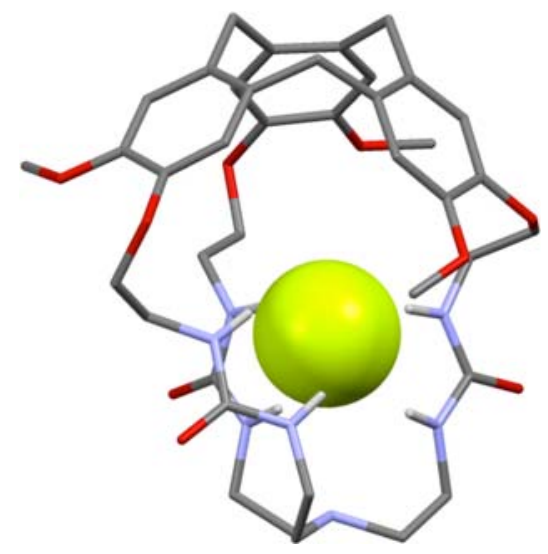

Figure 5. X-ray structure of $\left[3 \cdot \mathrm{F}^{-}\right] . \mathrm{TBA}^{+}$has been omitted for clarity.

We finally turned our attention on the selectivity factor: could the smaller hemicryptophane 3 result in a more selective binding of fluoride anion compared to its parent receptor 2 ? Other anions in the form of TBAX salts were therefore tested as potential guests, following the same procedure. Importantly, in marked contrast to cage 2 , no recognition occurs with the $\mathrm{I}^{-}, \mathrm{Br}^{-}, \mathrm{Cl}^{-}$halides as well as with the $\mathrm{AcO}^{-}$anion in the case of the new host 3 (Table 1). Furthermore, the strong affinity

Table 1. Comparison of the Association Constants $K_{\mathrm{a}}\left(\mathrm{M}^{-1}\right)$ for the 1:1 Complexes Formed between Anion Guests and Hemicryptophane Hosts 2 and 3

$\begin{array}{lrc}\text { guest }^{a} & K_{\mathrm{a}}\left(\mathrm{M}^{-1}\right), \text { host } 2^{b} & K_{\mathrm{a}}\left(\mathrm{M}^{-1}\right), \text { host } 3^{c} \\ \mathrm{~F}^{-} & 3900 & 1200 \\ \mathrm{Cl}^{-} & 4100 & <1 \\ \mathrm{Br}^{-} & 1050 & <1 \\ \mathrm{I}^{-} & 80 & <1 \\ \mathrm{AcO}^{-} & 1400 & <1 \\ \mathrm{H}_{2} \mathrm{PO}_{4}^{-} & 184,200 & 216\end{array}$

${ }^{a} \mathrm{TBA}^{+}$salt. ${ }^{b}$ From ref $10 .{ }^{c} K_{\mathrm{a}}$ was extracted from the ${ }^{1} \mathrm{H}$ NMR titration curves $\left(\mathrm{CDCl}_{3}, 500 \mathrm{MHz}, 298 \mathrm{~K}\right)$ for the proton $\mathrm{H}_{\mathrm{h}}(\delta=$ $4.71 \mathrm{ppm}$ for the free cage) using Bindfit software. ${ }^{15}$ Estimated error $10 \%$.

toward the $\mathrm{H}_{2} \mathrm{PO}_{4}{ }^{-}$anion, previously observed for the parent host $2\left(K_{\mathrm{a}}=184,200 \mathrm{M}^{-1}\right)$, was dramatically decreased in the case of its small analogue $3\left(K_{a}=216 \mathrm{M}^{-1}\right)$. Clearly, by reducing the size of the hemicryptophane's cavity, an impressive switch of selectivity is achieved with $\mathrm{K}_{\mathrm{F}}^{-} / \mathrm{K}_{\mathrm{H}_{2} \mathrm{PO}_{4}{ }^{-}}$ ratios of 0.02 and 5.56, respectively observed for 2 and 3 . Therefore, as proposed, the smaller and more rigid cavity of 3 results in a remarkable selectivity toward fluoride encapsulation over other small anions.

\section{CONCLUSIONS}

In conclusion, the 3-step synthesis of a novel hemicryptophane receptor owning three short ethylene linkers was described. We have shown that the tris-urea recognizing moiety of this host, coupled with its small inner space, results in a remarkable exclusive selectivity for fluoride over other halides. Indeed, this host does not recognize other small anions like $\mathrm{Cl}^{-}, \mathrm{I}^{-}, \mathrm{Br}^{-}$, or $\mathrm{AcO}^{-}$. The formation of a 1:1 host-guest complex with $\mathrm{F}^{-}$[3. $\mathrm{F}^{-}$] has been unambiguously evidenced by ESI-HRMS, ${ }^{1} \mathrm{H}$ $\mathrm{NMR}$, and ${ }^{19} \mathrm{~F}$ NMR analysis in solution. The postulated binding of $\mathrm{F}^{-}$at the six $\mathrm{NH}$ residues of 3 , through hydrogenbonding interactions, was demonstrated by X-ray diffraction analysis. Indeed, the first X-ray structure of a hemicryptophane host displaying an entrapped anionic guest is here reported. Altogether these results demonstrate that the design of trisurea hemicryptophane cages, owning a restricted and rigid cavity, is an approach to reach both selective and efficient $\mathrm{F}^{-}$ receptors. Future work in our laboratory will be devoted to the development of sensors built from this new cage structure for the electrochemical sensing of fluoride.

\section{EXPERIMENTAL SECTION}

Reactions were carried out with commercial grade solvents and starting material. Chromatography was performed with Merck $60 \mathrm{~A}$ $(0.040-0.063 \mathrm{~mm})$ silica gel. Merck silica gel $60 \mathrm{~F}_{254}$ plates were used for thin-layer chromatography. Melting points and IR spectra were determined using a Büchi Melting Point B-545 and a Bruker Alpha Platinum ATR, respectively. Either a Bruker AVANCE III HD 400 $\mathrm{MHz}$ spectrometer or a Bruker AVANCE III HD $300 \mathrm{MHz}$ was used to record the ${ }^{1} \mathrm{H}$ NMR and ${ }^{13} \mathrm{C}$ NMR. For both the ${ }^{1} \mathrm{H}$ NMR and ${ }^{13} \mathrm{C}$ NMR spectra, the chemical shifts $\delta$ are given in ppm and the coupling constant $J$ in $\mathrm{Hz}$ using the protonated residual solvent as the reference. ESI-HRMS was carried out on a SYNAPT G2 HDMS (Waters) mass spectrometer with API, and time-of-flight analysis provides the reported spectra. Measurements were realized with two internal standards. CTV-Br derivative $\mathbf{4}$ was obtained following published procedures. ${ }^{13}$

\section{SYNTHESIS}

Synthesis of CTV-N ${ }_{3}$ Derivative (5). ${ }^{18}$ To a solution of 4 $(1.30 \mathrm{~g}, 1.78 \mathrm{mmol})$ in dry DMF $(40 \mathrm{~mL})$ was added small portion of $\mathrm{NaN}_{3}(1.16 \mathrm{~g}, 17.8 \mathrm{mmol})$. The resulting mixture was then stirred overnight at $60{ }^{\circ} \mathrm{C}$ using an oil bath. After partial removing of the solvent under reduced pressure, $\mathrm{CH}_{2} \mathrm{Cl}_{2}(50 \mathrm{~mL})$ and water $(50 \mathrm{~mL})$ were added to the mixture. The aqueous layers were then separated and further extracted with $\mathrm{CH}_{2} \mathrm{Cl}_{2}(30 \mathrm{~mL})$. Combined organic layers were washed with water $(3 \times 30 \mathrm{~mL})$, dried over $\mathrm{MgSO}_{4}$, filtered, and evaporated to dryness. To the resulting yellow oil was added diethyl ether $(70 \mathrm{~mL})$, and the mixture was the stored for $6 \mathrm{~h}$ at $4{ }^{\circ} \mathrm{C}$. The resulting white solid was then washed with $\mathrm{Et}_{2} \mathrm{O}$ and filtrated, yielding $\mathbf{5}$ in a $98 \%$ yield (990 $\mathrm{mg}) .{ }^{1} \mathrm{H} \mathrm{NMR}\left(\mathrm{CDCl}_{3}, 300 \mathrm{MHz}, 298 \mathrm{~K}\right): \delta 6.93(\mathrm{~s}, 3 \mathrm{H}), 6.85$ $(\mathrm{s}, 3 \mathrm{H}), 4.75(\mathrm{~d}, J=13.7 \mathrm{~Hz}, 3 \mathrm{H}), 4.14(\mathrm{t}, J=5.2 \mathrm{~Hz}, 6 \mathrm{H})$, $3.83(\mathrm{~s}, 9 \mathrm{H}), 3.59-3.52(\mathrm{~m}, 9 \mathrm{H}) .{ }^{13} \mathrm{C} \mathrm{NMR}\left(\mathrm{CDCl}_{3}, 75 \mathrm{MHz}\right.$, $298 \mathrm{~K}): \delta 149.2,146.5,133.9,131.9,118.1,114.2,69.1,56.1$, 50.3, 36.4; IR: $\nu$ 2931, 2110, 1511, $1265 \mathrm{~cm}^{-1}$. HRMS (ESI) $m / z:[\mathrm{M}+\mathrm{Na}]^{+}$calcd for $\mathrm{C}_{30} \mathrm{H}_{33} \mathrm{~N}_{9} \mathrm{O}_{6} \mathrm{Na}, 638.2446$; found, 638.2442. $R_{f}: 0.23\left(\mathrm{CH}_{2} \mathrm{Cl}_{2}\right) \cdot \mathrm{mp} 137^{\circ} \mathrm{C}$.

Synthesis of Hemicryptophane (3). 5 (300 mg, 0.49 $\mathrm{mmol}$ ) and triphenylphosphine $(767 \mathrm{mg}, 2.9 \mathrm{mmol})$ were dissolved in dry tetrahydrofuran (THF) (10 mL) under an argon atmosphere. To the resulting mixture was bubbled carbon dioxide during $5 \mathrm{~min}$. The solution was then stirred under a $\mathrm{CO}_{2}$ atmosphere for $16 \mathrm{~h}$. After replacement of $\mathrm{CO}_{2}$ by argon, the mixture was stored in a syringe. A second syringe, containing a THF $(10 \mathrm{~mL})$ solution of tris-2-aminoethyl amine (72 $\mathrm{mg}, 0.49 \mathrm{mmol}$ ), was prepared. 
The solutions of the two syringes were added simultaneously dropwise in $140 \mathrm{~mL}$ of dry THF. The resulting mixture was stirred for an additional hour and evaporated to dryness. Purification by column chromatography on silica gel $\left(\mathrm{CH}_{2} \mathrm{Cl}_{2}\right.$ with a gradient of $\mathrm{MeOH}$ ) affords 3 as a white solid $(261 \mathrm{mg}$, $70 \%)$.

${ }^{1} \mathrm{H}$ NMR (300 MHz, $\left.\mathrm{CDCl}_{3}, 298 \mathrm{~K}\right): \delta 6.81(\mathrm{~s}, 1 \mathrm{H}, \mathrm{ArH})$, $6.80(\mathrm{~s}, 1 \mathrm{H}, \mathrm{ArH}), 4.95$ (br, $1 \mathrm{H}, \mathrm{NH}), 4.71(\mathrm{~d}, J=13.6 \mathrm{~Hz}$, $\left.1 \mathrm{H}, \mathrm{ArCH} \mathrm{H}_{2} \mathrm{Ar}\right), 4.54(\mathrm{br}, 1 \mathrm{H}, \mathrm{NH}), 4.14\left(\mathrm{~m}, 2 \mathrm{H}, \mathrm{OCH}_{2}\right), 3.90$ $\left(\mathrm{s}, 3 \mathrm{H}, \mathrm{OCH}_{3}\right), 3.74(\mathrm{~m}, 1 \mathrm{H}), 3.50(\mathrm{~d}, J=13.6 \mathrm{~Hz}, 1 \mathrm{H}$, $\left.\mathrm{ArCH}_{2} \mathrm{Ar}\right), 3.24(\mathrm{~m}, 1 \mathrm{H}), 2.36-2.15(\mathrm{br}, 4 \mathrm{H}) .{ }^{13} \mathrm{C} \mathrm{NMR}$ $\left(\mathrm{CDCl}_{3}, 298 \mathrm{~K}, 101 \mathrm{MHz}\right): \delta 158.5(\mathrm{C}=\mathrm{O}), 148.0\left(\mathrm{C}_{\mathrm{ar}} \mathrm{O}\right)$, $147.2\left(\mathrm{C}_{\mathrm{ar}} \mathrm{O}\right), 132.7\left(\mathrm{C}_{\mathrm{ar}}\right), 132.0\left(\mathrm{C}_{\mathrm{ar}}\right), 113.1\left(\mathrm{C}_{\mathrm{ar}} \mathrm{H}\right), 68.6$ $\left(\mathrm{OCH}_{2}\right), 56.2\left(\mathrm{OCH}_{3}\right), 41.0\left(\mathrm{NH}\left(\mathrm{CH}_{2}\right)_{2} \mathrm{~N}\right), 36.4$ $\left(\mathrm{ArCH}_{2} \mathrm{Ar}\right)$. HRMS (ESI) $\mathrm{m} / z$ : $[\mathrm{M}+\mathrm{H}]^{+}$calcd for $\mathrm{C}_{39} \mathrm{H}_{52} \mathrm{~N}_{7} \mathrm{O}_{9}, 762.3821$; found, 762.3821. mp $337{ }^{\circ} \mathrm{C}$. IR: $\nu$ $3344,2924,1641,1509,1258,1082,1015 \mathrm{~cm}^{-1}$.

Titration Experiments. To a solution of cage $3(2.5 \mathrm{mM}$ in $\mathrm{CDCl}_{3}, 500 \mu \mathrm{L}$ ), placed in an NMR tube, was added aliquots of a solution of guests ( $25 \mathrm{mM}$ in identical solvent). After each addition, chemical shifts $(\Delta \delta)$ of the receptor's protons resonating at $4.71 \mathrm{ppm}$ were measured and plotted as function of the [guest]/[host] ratio. Nonlinear least-squares fitting from the bindfit program (Thordarson's group) ${ }^{15}$ was used to extract association constants $K_{\mathrm{a}}$ from these plots.
(1) (a) Busschaert, N.; Caltagirone, C.; Van Rossom, W.; Gale, P. A. Applications of Supramolecular Anion Recognition. Chem. Rev. 2015, 115, 8038-8155. (b) Zhou, Y.; Zhang, J. F.; Yoon, J. Fluorescence and Colorimetric Chemosensors for Fluoride-Ion Detection. Chem. Rev. 2014, 114, 5511-5571. (c) Gschwind, F.; Rodriguez-Garcia, G.; Sandbeck, D. J. S.; Gross, A.; Weil, M.; Fichtner, M.; Hörmann, N. Fluoride ion batteries: theoretical performance, safety, toxicity, and a combinatorial screening of new electrodes. J. Fluor. Chem. 2016, 182, $76-90$.

(2) (a) Sessler, J. L.; Gale, P. A.; Cho, W.-S. Anion Receptor Chemistry; RSC Publishing: Cambridge, U.K., 2006. (b) Steed, J. W. Coordination and organometallic compounds as anion receptors and sensors. Chem. Soc. Rev. 2009, 38, 506-519. (c) Ballester, P. Anion Binding in Covalent and self-assembled molecular capsules. Chem. Soc. Rev. 2010, 39, 3810-3830. (d) Busschaert, N.; Caltagirone, C.; Van Rossom, W.; Gale, P. A. Applications of Supramolecular Anion Recognition. Chem. Rev. 2015, 115, 8038-8155. (e) Gale, P. A.; Caltagirone, C. Fluorescent and colorimetric sensors for anionic species. Coord. Chem. Rev. 2018, 354, 2-27. (f) Ji, X.; Chi, X.; Ahmed, M.; Long, L.; Sessler, J. L. Soft Materials Constructed Using Calix[4]pyrrole- and "Texas-Sized" Box-Based Anion Receptors. Acc. Chem. Res. 2019, 52, 1915-1927. (g) Kumar, R.; Sharma, A.; Singh, H.; Suating, P.; Kim, H. S.; Sunwoo, K.; Shim, I.; Gibb, B. C.; Kim, J. S. Revisiting Fluorescent Calixarenes: From Molecular Sensors to Smart Materials. Chem. Rev. 2019, 119, 9657-9721. (h) Langton, M. J.; Serpell, C. J.; Beer, P. D. Anion Recognition in Water: Recent Advances from a Supramolecular and Macromolecular Perspective. Angew. Chem., Int. Ed. 2016, 55, 1974-1987. (i) Lim, J. Y. C.; Beer, P. D. Sigma-Hole Interactions in Anion Recognition. Chem 2018, 4, 731-783. (j) Jolliffe, K. A. Pyrophosphate Recognition and Sensing in Water Using Bis[zinc(II)dipicolylamino]-Functionalized Peptides. Acc. Chem. Res. 2017, 50, 2254-2263.

(3) (a) Kim, S. K.; Lynch, V. M.; Sessler, J. L. Cone Calix[4]arene Diethyl Ester Strapped Calix[4]pyrrole: A Selective Receptor for the Fluoride Anion. Org. Lett. 2014, 16, 6128-6131. (b) Samanta, R.; Kumar, B. S.; Panda, P. K. Calix[4]pyrroles with Shortest Possible Strap: Exclusively Selective toward Fluoride Ion. Org. Lett. 2015, 17, 4140-4143. (c) Cametti, M.; Rissanen, K. Highlights on contemporary recognition and sensing of fluoride anion in solution and in the solid state. Chem. Soc. Rev. 2013, 42, 2016-2038. (d) Cametti, M.; Rissanen, K. Recognition and sensing of fluoride anion. Chem. Commun. 2009, 2809-2829. (e) Zhou, Y.; Zhang, J. F.; Yoon, J. Fluorescence and Colorimetric Chemosensors for Fluoride-Ion Detection. Chem. Rev. 2014, 114, 5511-5571. (f) Blackburn, O. A.; Routledge, J. D.; Jennings, L. B.; Rees, N. H.; Kenwright, A. M.; Beer, P. D.; Faulkner, S. Substituent effects on fluoride binding by lanthanide complexes of DOTA-tetraamides. Dalton Trans. 2016, 45, 3070-3077.

(4) (a) Motekaitis, R. J.; Martell, A. E.; Murase, I.; Lehn, J. M.; Hosseini, M. W. Comparative study of the copper(II) cryptates of CBISTREN and O-BISTREN. Protonation constants, formation constants, and secondary anion bridging by fluoride and hydroxide. Inorg. Chem. 1988, 27, 3630-3636. (b) Gale, P. A.; Sessler, J. L.; Král, V.; Lynch, V. Calix[4]pyrroles: Old Yet New Anion-Binding Agents. J. Am. Chem. Soc. 1996, 118, 5140-5141. (c) Ilioudis, C. A.; Tocher, D. A.; Steed, J. W. A Highly Efficient, Preorganized Macrobicyclic Receptor for Halides Based on $\mathrm{CH} \cdots$ and $\mathrm{NH}$...Anion Interactions. J. Am. Chem. Soc. 2004, 126, 12395-12402. (d) Chudzinski, M. G.; McClary, C. A.; Taylor, M. S. Anion Receptors Composed of Hydrogen- and Halogen-Bond Donor Groups: Modulating Selectivity 
With Combinations of Distinct Noncovalent Interactions. J. Am. Chem. Soc. 2011, 133, 10559-10567. (e) Montis, R.; Bencini, A.; Coles, S. J.; Conti, L.; Fusaro, L.; Gale, P. A.; Giorgi, C.; Horton, P. N.; Lippolis, V.; Mapp, L. K.; Caltagirone, C. Fluoride binding by an anionic receptor: tuning the acidity of amide $\mathrm{NH}$ groups for basic anion hydrogen bonding and recognition. Chem. Commun. 2019, 55, $2745-2748$

(5) (a) Dalla Cort, A.; Forte, G.; Schiaffino, L. Anion Recognition in Water with Use of a Neutral Uranyl-salophen Receptor. J. Org. Chem. 2011, 76, 7569-7572. (b) Cametti, M.; Dalla Cort, A.; Bartik, K. Fluoride Binding in Water: A New Environment for a Known Receptor. ChemPhysChem 2008, 9, 2168-2171. (c) Cametti, M.; Dalla Cort, A.; Mandolini, L.; Nissinen, M.; Rissanen, K. Specific recognition of fluoride anion using a metallamacrocycle incorporating a uranyl-salen unit. New J. Chem. 2008, 32, 1113-1116.

(6) (a) Zhao, H.; Gabbaï, F. P. A bidentate Lewis acid with a telluronium ion as an anion-binding site. Nat. Chem. 2010, 2, 984990. (b) Chen, C.-H.; Gabbaï, F. P. Exploiting the Strong Hydrogen Bond Donor Properties of a Borinic Acid Functionality for Fluoride Anion Recognition. Angew. Chem., Int. Ed. 2018, 57, 521-525.

(7) (a) Hirai, M.; Gabbaï, F. P. Squeezing Fluoride out of Water with a Neutral Bidentate Antimony(V) Lewis Acid. Angew. Chem., Int. Ed. 2015, 54, 1205-1209. (b) Chen, C.-H.; Gabbaï, F. P. Fluoride Anion Complexation by a Triptycene-Based Distiborane: Taking Advantage of a Weak but Observable C-H...F Interaction. Angew. Chem., Int. Ed. 2017, 56, 1799-1804.

(8) Brugnara, A.; Topić, F.; Rissanen, K.; Lande, A. d. 1.; Colasson, B.; Reinaud, O. Selective recognition of fluoride anion in water by a copper(II) center embedded in a hydrophobic cavity. Chem. Sci. 2014, 5, 3897-3904.

(9) Liu, W.; Oliver, A. G.; Smith, B. D. Stabilization and Extraction of Fluoride Anion Using a Tetralactam Receptor. J. Org. Chem. 2019, $84,4050-4057$.

(10) Delecluse, M.; Colomban, C.; Moraleda, D.; de Riggi, I.; Duprat, F.; Michaud-Chevallier, S.; Dutasta, J. P.; Robert, V.; Chatelet, B.; Martinez, A. Positive Cooperative Effect in Ion-Pair Recognition by a Tris-urea Hemicryptophane Cage. Chem.-Eur. J. 2019, 25, 3337-3342.

(11) Perraud, O.; Robert, V.; Martinez, A.; Dutasta, J.-P. The Cooperative Effect in Ion-Pair Recognition by a Ditopic Hemicryptophane Host. Chem.-Eur. J. 2011, 17, 4177-4182.

(12) Han, H. J.; Oh, J. H.; Sessler, J. L.; Kim, S. K. Small triiminopyrrolic molecular cage with high affinity and selectivity for fluoride. Chem. Commun. 2019, 55, 10876-10879.

(13) Chatelet, B.; Payet, E.; Perraud, O.; Dimitrov-Raytchev, P.; Chapellet, L.-L.; Dufaud, V.; Martinez, A.; Dutasta, J.-P. Shorter and Modular Synthesis of Hemicryptophane-tren Derivatives. Org. Lett. 2011, 13, 3706-3709.

(14) Zhang, D.; Martinez, A.; Dutasta, J.-P. Emergence of Hemicryptophanes: From Synthesis to Applications for Recognition, Molecular Machines, and Supramolecular Catalysis. Chem. Rev. 2017, $117,4900-4942$.

(15) Hibbert, D. B.; Thordarson, P. The death of the Job plot, transparency, open science and online tools, uncertainty estimation methods and other developments in supramolecular chemistry data analysis. Chem. Commun. 2016, 52, 12792-12805. http://app. supramolecular.org/bindfit/

(16) Goursaud, M.; De Bernardin, P.; Dalla Cort, A.; Bartik, K.; Bruylants, G. Monitoring Fluoride Binding in DMSO: Why is a Singular Binding Behavior Observed? Eur. J. Org. Chem. 2012, 2012, $3570-3574$

(17) The X-ray structure revealed a disorder within the cage where the guest was found to be a mix of fluoride $\left(\left[3 \cdot \mathrm{F}^{-}\right]\right)$with $90 \%$ occupation site, and a water molecule $\left(\left[3 \cdot \mathrm{H}_{2} \mathrm{O}\right]\right)$ with $10 \%$ occupation site within the crystal (see Figure S10).

(18) Long, A.; Perraud, O.; Albalat, M.; Robert, V.; Dutasta, J.-P.; Martinez, A. Helical Chirality Induces a Substrate-Selectivity Switch in Carbohydrates Recognitions. J. Org. Chem. 2018, 83, 6301-6306. 